\title{
Análise dos usos, coberturas e ocupação da terra no município de Canguçu/RS
}

\author{
Analysis of land use, land cover and land occupation in the municipality of Canguçu/RS
}

\author{
Danilo da Silva Dutra \\ Doutor em geografia pela Universidade Federal do Rio Grande do Sul, Brasil \\ danilodasilvadutra@hotmail.com \\ Luís Eduardo de Souza Robaina \\ Professor Doutor do Departamento de Geociências na \\ Universidade Federal de Santa Maria, Brasil \\ lesrobaina@yahoo.com.br
}

\section{Resumo}

Os estudos de uso e ocupação da terra são importantes nas análises ambientais pois permitem identificar a condição das relações entre a sociedade e a natureza. Diante desse contexto, o objetivo do trabalho é a análise dos usos, coberturas e ocupação da terra no município de Canguçu/RS/Brasil. Para desenvolver esse trabalho fez-se pesquisas em sites de diferentes instituições e de imagens de satélite de média resolução espacial, além de trabalhos de campo. Com as imagens de satélite do Sentinel 2B fez-se composição colorida natural e classificação digital supervisionada. A partir de trabalhos de campo observou-se acurácia cartográfica dos usos e coberturas da terra mapeados quanto satisfatória. Como resultados observou-se características típicas da agricultura familiar, apesar da presença de latifúndios associados, principalmente as áreas mais ao Norte. Essas características contribuem com teorias que afirmam que Canguçu é a capital brasileira da agricultura familiar. Dos usos e coberturas, predominam as coberturas nativas como os campos e matas, importantes potencialidades ambientais. As lavouras de maior porte e a silvicultura são importantes na porção Norte do município. Com essa pesquisa espera-se contribuir com o conhecimento do ambiente que caracteriza a área de estudo, e dessa forma, despertar para as ações de gerenciamento ambiental do município de Canguçu.

Palavras-chave: Coberturas, Usos e ocupação da terra, Canguçu/RS.

\begin{abstract}
Studies of land use and occupation are important in environmental analysis as it allows to identify the condition of the relationships between society and nature. In this context, the objective of the work is to analyze the uses, coverage and occupation of land in the city of Canguçu/RS/Brazil. For this, research was carried out on websites of different institutions and medium spatial resolution satellite images and fieldwork. Natural colour composite and supervised digital classification were performed with the Sentinel 2B satellite images. The cartographic accuracy of land uses and land cover mapped as satisfactory was observed from fieldwork. As a result, typical characteristics of family farming were observed, despite associated latifundia, mainly in the northernmost areas. This characteristic contributes to theories that claim that Canguçu is the Brazilian capital of family farming. The land uses and land cover predominates native land cover such as fields and forests, important environmental potential. In addition, larger crops and forestry are important in the northern portion of the municipality. This research is expected to contribute to the knowledge of the environment that characterizes the study area, thus awakening to environmental management actions in the city of Canguçu.
\end{abstract}

Keywords: Land cover, Land use and occupation, Canguçu/RS. 


\section{INTRODUÇÃO}

A ciência geográfica possibilita o estudo da relação sociedade e natureza como aspectos inseparáveis, pois todos constituem o planeta Terra. Sabe-se que, ao longo da maior parte da existência humana na Terra, estabeleceram-se relações harmônicas com o ambiente; no entanto, em uma pequena fração desse tempo até o período atual, a sociedade intensificou drasticamente sua ação sobre o ambiente. O resultado disso é uma desestabilização nessa relação ao ponto de comprometer nossa própria existência (ARENDT, 1987).

Ao abordar essa questão da evolução humana e da degradação ambiental, Cunha e Guerra (2010, p. 339) enfatizam que "no decorrer da história, com o aparecimento do homem no pleistoceno, com a evolução das forças produtivas, a natureza vai sendo apropriada e transformada". Tratando dessa mesma temática, as relações sociedade e natureza, Bernardes e Ferreira (2012, p. 17) explicam que:

A compreensão tradicional das relações entre a sociedade e a natureza desenvolvidas até o século XIX, vinculadas ao processo de produção capitalista, considerava o homem e a natureza como polos excludentes, tendo subjacente a concepção de uma natureza objeto, fonte ilimitada de recursos à disposição do homem.

Esse tipo de relação mencionada na citação supracitada conduziu a sociedade a uma complexidade ambiental, o que, na atualidade, nos faz refletir sobre alternativas que analisem as ações humanas sobre o ambiente. Enquanto sociedade, precisamos encontrar outras maneiras de relação com o ambiente de modo a contornar essa questão.

A problemática ambiental tem se refletido nos diferentes campos do conhecimento científico, podendo-se destacar o campo das geociências. Enquanto fatos das questões ambientais, destacam-se a perda dos horizontes dos solos e o assoreamento dos cursos fluviais, que são resultantes de práticas inadequadas com a terra. Esses dois problemas vêm ocasionando a redução da capacidade de produção da terra e o comprometimento dos recursos hídricos.

Diante desse contexto, são necessários estudos que visam conhecer a realidade socioeconômica avaliando os tipos de usos, coberturas e ocupação da terra. Nesse sentido, o objetivo da pesquisa é realizar a cartografação e análise desses atributos do município de Canguçu para contribuir com o gerenciamento ambiental.

Como trata-se de um estudo sobre uma área física municipal, considera-se o uso de imagens de satélite de média resolução espacial como adequadas a esse propósito, visto que as mesmas tem um grau de detalhamento considerável. Chaves et al (2020) consideram as imagens do satélite Sentinel-2/MSI importantes para a produção de mapas precisos e demonstram potencial para o mapeamento de usos e coberturas da terra heterogêneos, como os que caracterizam a área de estudo. 


\subsection{Localização e caracterização da área de estudo}

Canguçu está localizado no Sul do estado do Rio Grande do Sul (RS), entre as seguintes coordenadas geográficas: $30^{\circ} 53^{\prime} 06^{\prime \prime}$ a $31^{\circ} 40^{\prime} 06^{\prime \prime}$ de latitude sul da Linha do Equador, e 52 $59^{\prime} 28^{\prime \prime}$ a $52^{\circ} 14^{\prime} 21^{\prime \prime}$ de longitude oeste (Figura 1). No contexto do estado, ocupa área oficial de expressiva dimensão física, 3.525,293 $\mathrm{km}^{2}$ (IBGE, 2019). Em seu território, devido a suas características físicas, encontram-se as nascentes de muitos afluentes de importantes cursos fluviais da região, a destacar a nascente dos arroios Quilombo e Caneleiras que, no município de Pelotas, serão designados como Arroio Pelotas. Também se situam importantes afluentes dos rios Piratini e Camaquã.

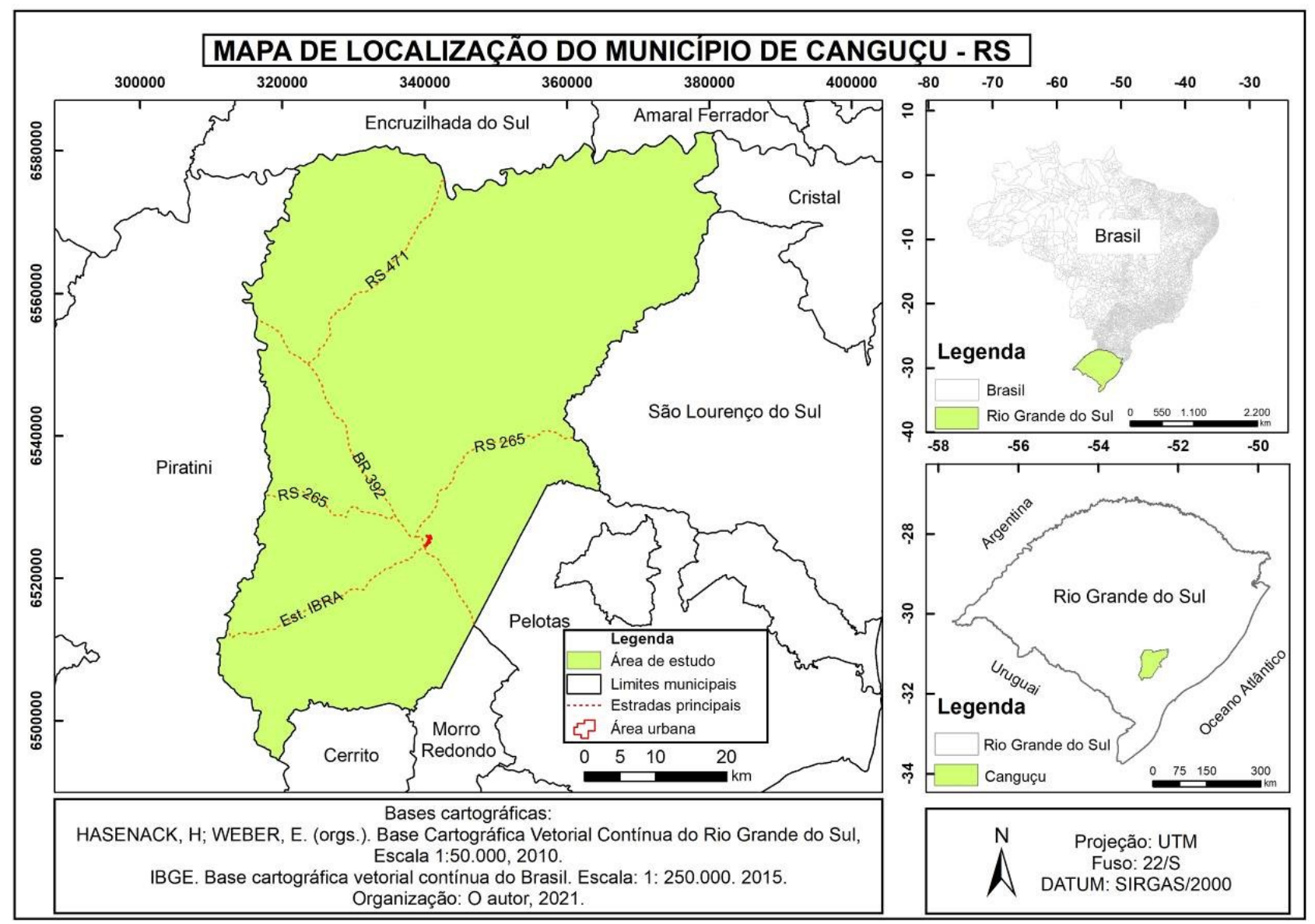

Figura 1 - Localização da área de estudo Organização: Os autores (2021).

O município conta com uma população de 53.259 habitantes e densidade demográfica de 15,11 hab. $/ \mathrm{km}^{2}$ (IBGE, 2010) e foi fundado na data de 27 de junho de 1857 (BENTO, 2007). Apesar de não haver consenso sobre a origem do nome Canguçu, a teoria mais aceita é a que explica sua origem a partir da referência à palavra indígena "Caa-guassu" com o sentido de "mato grande" como referência à densa floresta que existia nessa região (BENTO, 2007). 
Segundo dados sistematizados pela Prefeitura Municipal de Canguçu (2019), o município é um dos maiores produtores de fumo do Brasil, além de representar importante polo da pecuária gaúcha. De acordo com Dutra (2015), a fumicultura é uma das responsáveis pelo aporte de capitais e renda para as famílias, e é também o setor que tem impulsionado o dinamismo do setor terciário no município.

\section{METODOLOGIA}

As informações e bases cartográficas da pesquisa estão sintetizadas na Figura 2. Para todos os procedimentos de SIG e de técnicas de geoprocessamento usados, fez-se uso do software ArcGIS 10.5 disponível no laboratório de geologia ambiental LAGEOLAM-UFSM.

\begin{tabular}{|c|c|}
\hline Dados/atributos & Fonte \\
\hline $\begin{array}{c}\text { Informações } \\
\text { socioeconômicas e } \\
\text { históricas do município }\end{array}$ & $\begin{array}{l}\text { Instituto Brasileiro de Geografia e Estatística (IBGE); Fundação de economia e } \\
\text { Estatística (FEE); Instituto Nacional de Colonização e Reforma Agrária (INCRA); } \\
\text { Empresa de Assessoria Técnica Rural (EMATER-Canguçu); Prefeitura Municipal de } \\
\text { Canguçu (PMC). }\end{array}$ \\
\hline Cartografia de Base & Hasenack e Weber (2010), Escala de 1:50.000 e IBGE (2015), Escala de 1:250.000. \\
\hline Hidrografia & Secretaria do Meio Ambiente/RS, (SEMA-2018), Escala de 1:25.000. \\
\hline Usos e coberturas da terra & $\begin{array}{l}\text { Na realização desse mapeamento, as imagens foram obtidas do satélite Sentinel 2B, } \\
\text { sensor MSI - Instrumento Multiespectral, disponibilizadas no site da Agência Espacial } \\
\text { Europeia (ESA). } \\
\text { Os usos e coberturas da terra foram cartografados a partir de técnicas de } \\
\text { sensoriamento remoto. Realizou-se o Processamento Digital de Imagens (PDI) de } \\
\text { satélite de média resolução espacial (10 metros), mediante a elaboração de } \\
\text { composição colorida com as bandas (4/3/2/8, composição colorida natural) de } 16 \text { bits, } \\
\text { classificação digital supervisionada, além da realização de interpretação de imagens } \\
\text { de alta resolução espacial ( } 1 \mathrm{~m}) \text { e trabalhos de campo. }\end{array}$ \\
\hline Ocupação & PMC-2008, escala de 1:75.000; INCRA e EMATER-Canguçu. \\
\hline
\end{tabular}

Figura 2: Informações utilizadas na operacionalização da pesquisa.

Organização: Os autores, 2021.

\subsection{Usos e coberturas da terra}

Na realização desse mapeamento, as imagens foram obtidas do mês de março de 2019, pois se obteve uma melhor resposta espectral na identificação dos usos e coberturas relativas a solo exposto e lavouras. Nesse período do ano, final da estação verão, e na área de estudo, as lavouras de fumo já estão colhidas e as de soja já se encontram em fase de maturação e colheita.

Para geração do produto cartográfico em questão, e em ambiente SIG, foram identificadas e coletadas um total de aproximadamente 300 amostras para os tipos de usos e coberturas da terra destacados a seguir: mata nativa, silvicultura, lavoura, campo nativo e solo exposto. Essas amostras 
foram diferenciadas, identificadas e coletadas com base nas orientações de Florenzano (2008) e IBGE (2013), ou seja, com base na cor, forma, arranjos e textura da imagem.

No mapa de usos e coberturas da terra, também foram identificadas as áreas úmidas. Para isso, e devido a confusão espectral com os demais usos e coberturas da terra, utilizou-se da base cartográfica da SEMA (2018), referente ao atributo de áreas úmidas.

Após a identificação das amostras referentes aos usos e coberturas da terra, acessou-se a ferramenta Maximum Likelihood Classification e realizou-se a identificação automatizada dos usos e coberturas da terra. Num segundo momento, a fim de se proceder a uma maior homogeneização desse parâmetro, utilizou-se a ferramenta Majority para realização de uma limpeza de eventuais pixels espúrios.

\subsubsection{Verificação da acurácia cartográfica do mapeamento dos usos e coberturas da terra}

No intuito de verificação da acurácia cartográfica desse atributo em questão, foram observadas as proposições de Valeriano (1984). Esse autor apresenta uma metodologia muito importante e de fácil aplicação, que pode ser útil em qualquer contexto e, principalmente, quando o pesquisador tem conhecimento e acesso sobre a área de estudo.

Nesse sentido, a verificação da acurácia cartográfica desse atributo foi realizada através de trabalhos de campo, a partir da observação da classe de uso e ou cobertura que ocorre em cada ponto e sua verificação em gabinete para constatar a verdade absoluta.

Segundo orientações metodológicas de Valeriano (1984), a acreção de cada 10 amostras de uso e cobertura da terra, e havendo consecutivos resultados positivos com confirmações em gabinete superiores a $90 \%$ (interpretação nossa), considerou-se os resultados cartográficos apresentados de alta qualidade, portanto, aceitáveis.

Com base na metodologia de verificação cartográfica apresentada por Valeriano (1984), é apresentada, na Tabela 1, o número de pontos de campo, o número de pontos com usos e coberturas classificados corretamente, ou não. Nessa tabela, é apresentado o percentual de pontos classificados corretamente conforme proporção de acréscimos de 10 ao tamanho da mostra.

Tabela 1 - Relação de pontos classificados em campo versus realidade produzida em gabinete

\begin{tabular}{c|c|c|c}
$\begin{array}{c}\text { Número de } \\
\text { pontos de } \\
\text { campo }\end{array}$ & \multicolumn{2}{|c|}{$\begin{array}{c}\text { Número de pontos de campo } \\
\text { classificados corretamente, ou não }\end{array}$} & $\begin{array}{c}\text { Percentual de pontos classificados } \\
\text { corretamente conforme proporção de } \\
\text { acréscimos de 10 ao tamanho da mostra }\end{array}$ \\
\cline { 2 - 3 } & Sim & Não & $94,17 \%$ \\
\hline 120 & 113 & 7 & \\
\hline
\end{tabular}

Organização: Os autores, 2021. 
A partir dessa tabela, observa-se uma precisão do produto cartográfico apresentado, superior a 94\%. Os pontos que se mostraram errôneos relacionam-se às classes de solo exposto e lavouras, destacando-se que, no geral, essas duas classes transformam-se periodicamente, ou seja, uma área que era lavoura posteriormente pode vir a caracterizar-se como solo exposto e vice-versa.

\subsection{Dados da ocupação}

Em SIG e a partir da definição de janelas com áreas de $5 \mathrm{~km}$ por $5 \mathrm{~km}$, valores condizentes com a representatividade que requer os objetivos da pesquisa, foi calculada a densidade ocupacional média para a área de estudo. De 0 a $1,5 \mathrm{mnh} / \mathrm{km}^{2}$, considerou-se área de baixa densidade ocupacional, entre 1,5 até $2,5 \mathrm{mnh} / \mathrm{km}^{2}$, considerou-se média e, acima de $2,5 \mathrm{mnh} / \mathrm{km}^{2}$, considerouse alta.

Outra importante informação relacionada na pesquisa são os assentamentos da reforma agrária. Para levantamento dessas informações, foi consultado o site do INCRA, onde acessou-se a base, em formato shapefile, dos assentamentos federais localizados no município. Para identificação dos assentamentos estaduais, foi realizado uma consulta presencial à sede da EMATER-Canguçu quando os técnicos desse órgão disponibilizaram a localização geográfica desses assentamentos.

Para a pesquisa, foram realizados trabalhos de campo tanto para reconhecimento da área de estudo como para observar tipos de coberturas e ocupação da terra, para o registro de informações, bem como confrontar a realidade produzida em gabinete com a realidade concreta. Por fim, permitiram a validação dos produtos da pesquisa (mapas de usos, coberturas e ocupação da terra).

\section{ANÁLISE DA OCUPAÇÃO}

Em um primeiro momento da povoação do município de Canguçu sobressai-se a pecuária extensiva, característica associada à vinda de colonizadores portugueses auxiliados pelos escravos africanos. Entretanto, conforme De David (2005, p.37), tratando do contexto estadual

Como as grandes estâncias de criação de gado não garantiam o povoamento efetivo do território, o governo português promoveu a vinda de imigrantes açorianos destinados a ocupar a região e desenvolver atividades diversificadas, entre as quais a produção agrícola e $\mathrm{o}$ artesanato.

Em um segundo momento, ainda de acordo com De David (2005) o Rio Grande do Sul começa uma diversificação produtiva, principalmente com o auxílio de imigrantes alemães e italianos, os quais passam a desenvolver atividades típicas da pequena propriedade e com mão de obra familiar. No caso específico do município de Canguçu, segundo Viera (2012, p.28) 
As áreas mais férteis e planas foram destinadas à pecuária extensiva (Colinas). Já nas áreas com declives acentuados foi permitida a ocupação por pequenos agricultores, que destinavam sua produção basicamente ao abastecimento do grupo familiar (Cristas).

Cotrim (2003) observou no município de Canguçu duas zonas distintas: a "zona de campo" e a "zona de floresta" (Figura 3). A primeira espacializa-se no sentido norte e oeste do município e é caracterizada por grandes propriedades rurais - "estâncias" oriundas do regime de sesmarias e doadas a militares portugueses por volta do ano de 1756 -, de ocupação mais rápida. A segunda zona espacializa-se no sentido sul-leste, de ocupação mais lenta e caracterizada pela diversificação produtiva.

O município é formado por 5 distritos e 120 localidades. O primeiro distrito está localizado no Centro, incluindo a área urbana; o segundo distrito está localizado, sobretudo, ao sudeste; o terceiro distrito está ao noroeste; o quarto distrito está ao sul, e o quinto distrito está localizado ao nordeste (Figura 4).

Analisando as características econômico-fundiárias de Canguçu, Viera (2012) observa que o primeiro, o segundo e o quarto distrito têm sistemas de cultivo diversificados, voltados à subsistência das famílias. O terceiro e o quinto distrito são caracterizados, predominantemente, por grandes propriedades, principalmente com a pecuária de corte. Ainda assim, ultimamente observase que o quarto distrito de Canguçu apresenta-se em estágio de transição entre as grandes propriedades e a agricultura familiar. Provavelmente, isso tem ocorrido em virtude do abandono do campo pelos jovens - aspecto também observado por Bandeira (2017) - e por esse distrito se encontrar mais distante da sede do município.

A partir de dados apresentados por Bandeira (2017), com base em informações disponibilizadas pela Secretaria Municipal de Agricultura de Canguçu (2010), distinguem-se diversos estratos fundiários no município. O estrato fundiário predominante em Canguçu, mais de $61 \%$, representa a agricultura familiar, e pouco mais de $1 \%$ das propriedades representam grandes extensões de terra. O fato de Canguçu ser conhecido como o maior minifúndio brasileiro (Grigoletti, 2000) ou, de acordo com Bandeira (2017), como a capital nacional da agricultura familiar, tem relações com as sucessões hereditárias que foram ocorrendo no município, as quais também estão relacionadas ao grande número de filhos por casais.

$\mathrm{Na}$ Figura 5, tem-se o macrozoneamento rural de Canguçu realizado pela Prefeitura Municipal para o quadriênio 2018-2022. Nesse zoneamento são definidas três zonas: agricultura familiar, pecuária familiar e pecuária extensiva.

A zona de pecuária extensiva, menos representativa em área, caracteriza o norte e o noroeste de Canguçu. A zona de pecuária familiar caracteriza o norte, centro e sul da área de estudo e a zona 
de agricultura familiar dissemina-se em todas as direções geográficas, inclusive sendo a zona predominante.

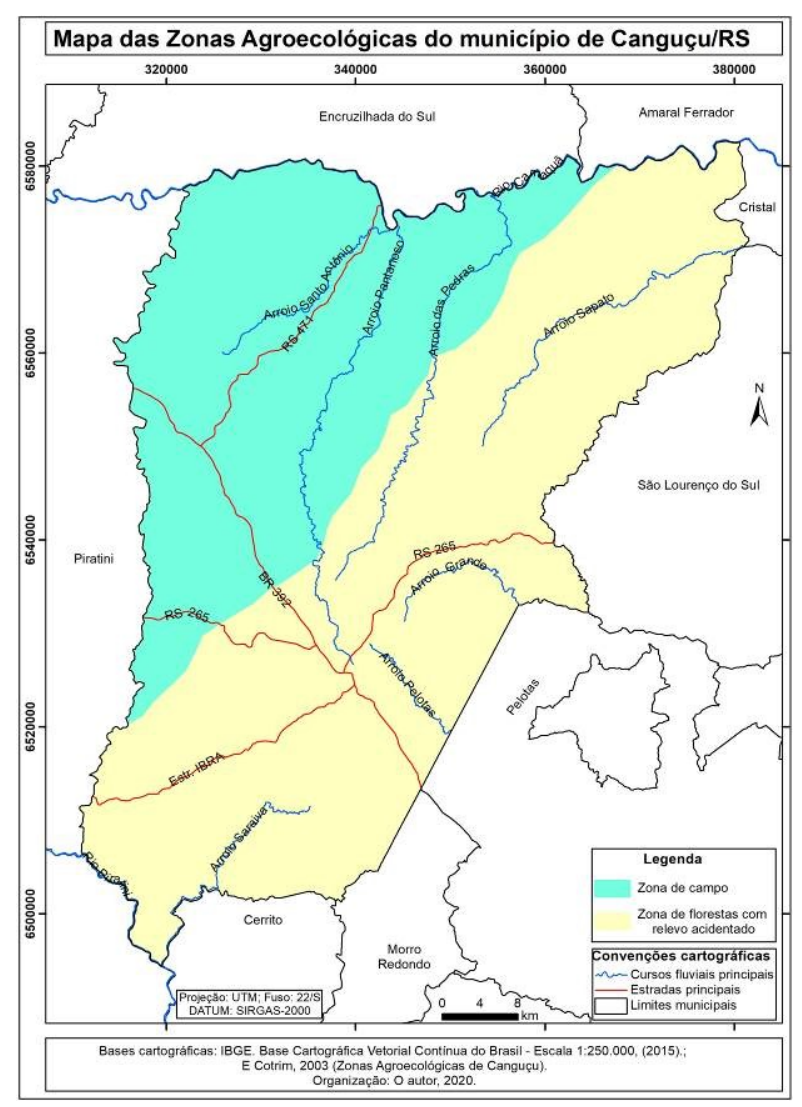

Figura 3: Mapas de zonas Agroecológicas, adaptado de Cotrim (2003). Organização: Os autores, 2021.

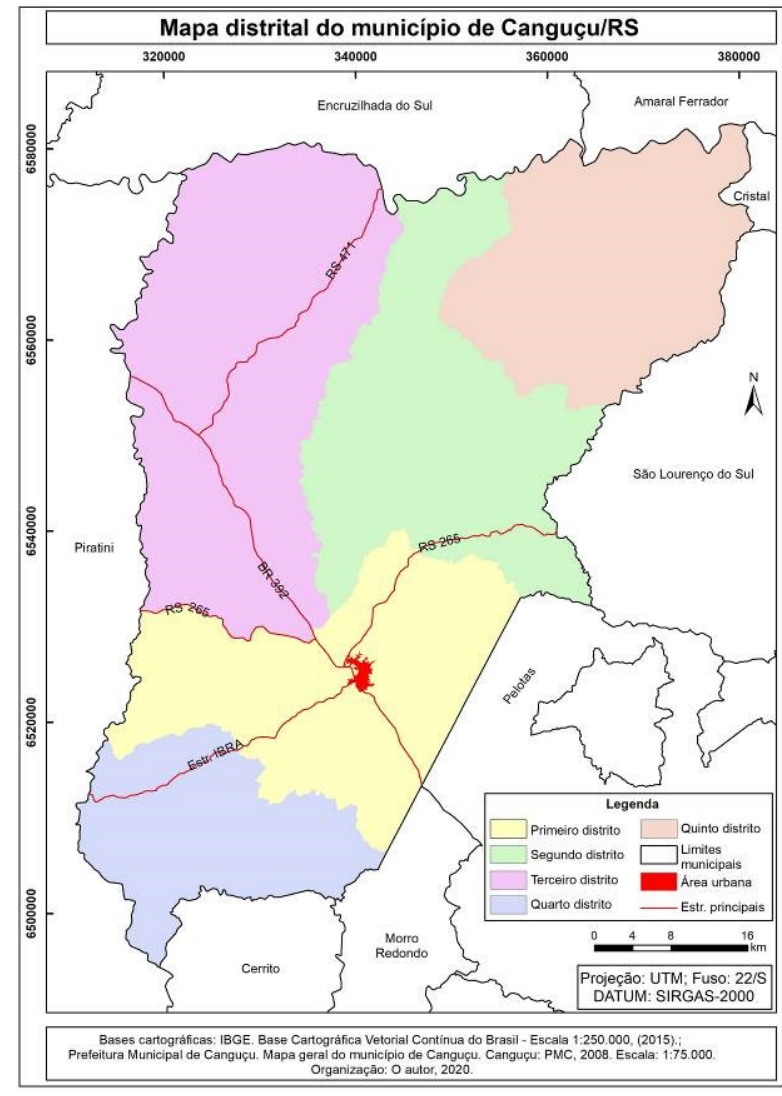

Figura 4: Distritos que formam o município de Canguçu. Organização: Os autores, 2021.

Bandeira (2017) observou que apesar de a produção de fumo ainda ser expressiva no município, inclusive como o principal gerador de renda, o cultivo de soja está avançando, sendo ele o reflexo de algumas mudanças sociodemográficas, como a migração dos jovens do campo para a cidade.

Com base no censo agropecuário do IBGE 2017, o uso relativo a lavouras permanentes que mais se destaca em ocupação territorial é o pêssego, com 939 hectares e 221 estabelecimentos envolvidos, seguido pelas oliveiras, com 345 hectares.

Com relação a Silvicultura destaca-se Ehlert (2010), que indica que somente com o programa Poupança Florestal, em Canguçu, com um total de 25 silvicultores que, juntos, cultivavam mais de 752 hectares. Ainda conforme o mesmo autor, duas empresas particulares, também somadas, cultivavam aproximadamente seis mil hectares de silvicultura. Isso refletiu com menor desmatamento da cobertura arbórea nativa para servir na cura do fumo, visto que a maioria dos fumicultores tem suas próprias florestas cultivadas e quando não dispõem delas, compram essa matéria-prima. Um outro fenômeno que outrora também preocupava pelo desmatamento irregular 
eram as carvoarias. Ultimamente esse fator tem diminuído drasticamente, pois o mercado exige procedência, o que deixa os carvoeiros que usam lenha nativa à margem, e por consequência abandonam suas atividades, fato ambientalmente positivo.

Em âmbito geral, considera-se que o fator que mais ameaça as matas nativas, e principalmente áreas de nascentes e matas ciliares, é a expansão de lavouras de soja, quando os sojicultores, tencionando aumentar suas áreas de produção, não respeitam as áreas de preservação permanentes.

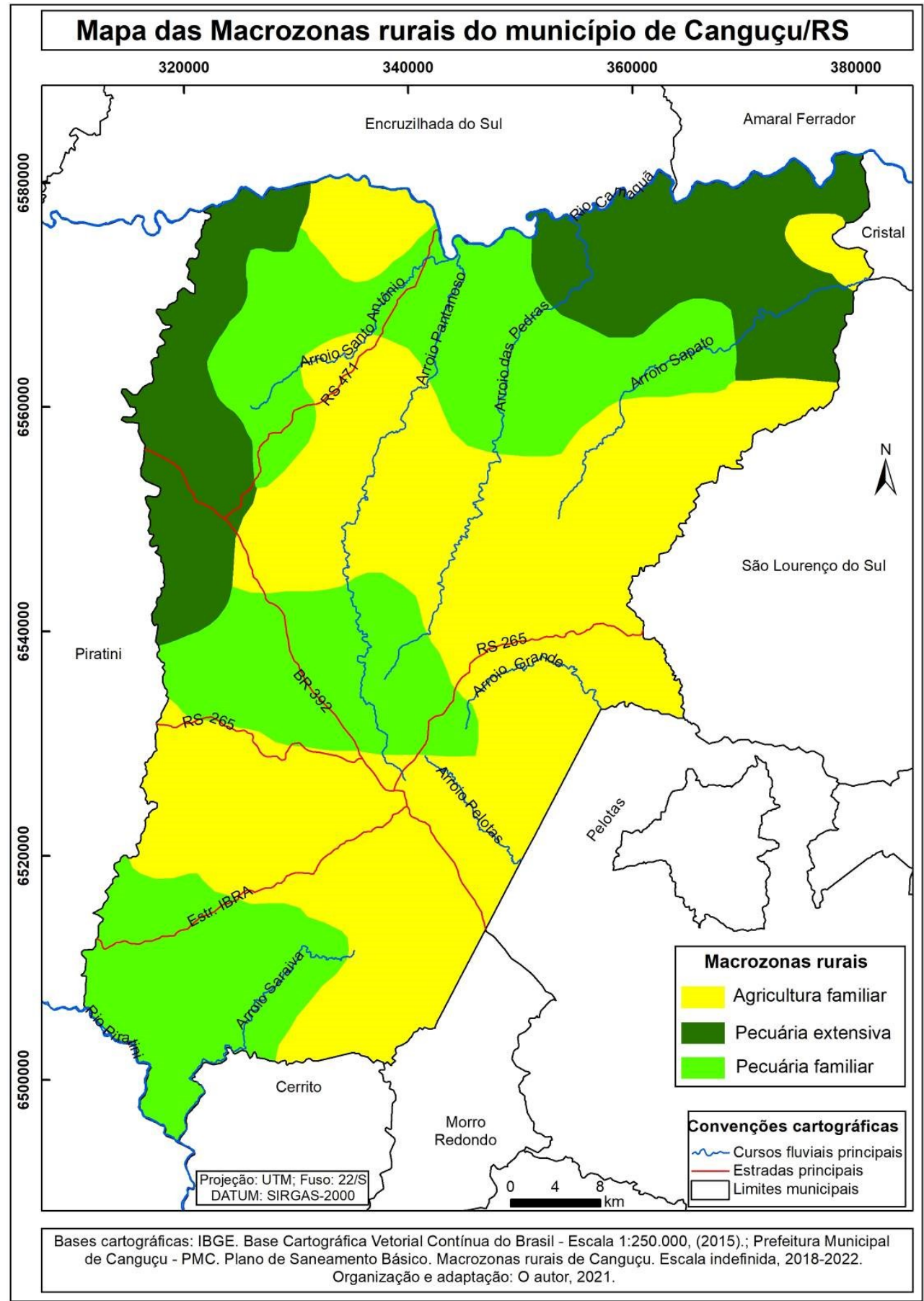

Figura 5 - Macrozonas rurais. Fonte: Adaptado de PMC (2018)

Organização: Os autores 2021 


\subsection{Aspectos demográficos}

Segundo o IBGE (2010), os dados projetados para a população do município de Canguçu, em 2019, de 56.045 habitantes, sendo a população rural de 33.565 habitantes e população urbana de 19.694 habitantes, portanto mais de $63 \%$ de sua população vive no campo.

Estatisticamente, o distrito canguçuense com maior densidade ocupacional por MNH é o primeiro distrito, com $3,10 \mathrm{mnh} / \mathrm{km}^{2}$, e com a menor taxa é o quinto distrito, com $1,04 \mathrm{mnh} / \mathrm{km}^{2}$. Os demais distritos têm as seguintes densidades ocupacionais: segundo distrito: 2,94 $\mathrm{mnh} / \mathrm{km}^{2}$; quarto distrito: 2,23 mnh/ $\mathrm{km}^{2}$; e o terceiro distrito: $1,21 \mathrm{mnh} / \mathrm{km}^{2}$ (PMC, 2008) (Tabela 2).

Tabela 2 - Densidade demográfica distrital

\begin{tabular}{c|c|c}
\hline Distrito & População absoluta & Densidade demográfica hab./km $\mathbf{~}^{\mathbf{2}}$ \\
\hline Primeiro & 31.173 & 44,63 \\
\hline Segundo & 8.623 & 11,40 \\
\hline Terceiro & 5.889 & 5,79 \\
\hline Quarto & 4.325 & 10,25 \\
\hline Quinto & 3.249 & 5,14 \\
\hline
\end{tabular}

Fonte: Dados extraídos de IBGE (2010); Organização: Os autores, 2021

Na Figura 6, tem-se a espacialização da ocupação da área de estudo. Nessa figura é possível observar, principalmente no Terceiro e Quinto distrito, vazios ocupacionais e, em contrapartida, áreas densamente povoadas no Primeiro e Segundo distrito. Também se analisou a densidade ocupacional da área de estudo destacando-se o predomínio de áreas com baixa densidade ocupacional, localizada ao oeste e norte-nordeste municipal, seguidas pelas áreas de alta densidade ocupacional, estando localizadas ao sudeste e leste do município (Figura 7).

Uma característica singular, da área de estudo, é sua realidade quanto ao número de assentamentos rurais da Reforma Agrária. De acordo com dados do INCRA, atualizados em 31/12/2017, existiam no Rio Grande do Sul 345 assentamentos, congregando 12.413 famílias. Em Canguçu, conforme essa mesma fonte, são 16 assentamentos com cerca de 400 famílias assentadas (Figura 8)

Diante desses dados apresentados, considera-se a área de estudo um importante polo de assentamentos rurais, fato que, segundo De David (2005) e Viera (2012), se dá em virtude do baixo valor comercial das terras desse município e, ao mesmo tempo, da importância de agregar valor a esse lugar. Os assentamentos estão localizados principalmente ao norte do município, no quinto distrito, onde se situam um total de onze assentamentos. 


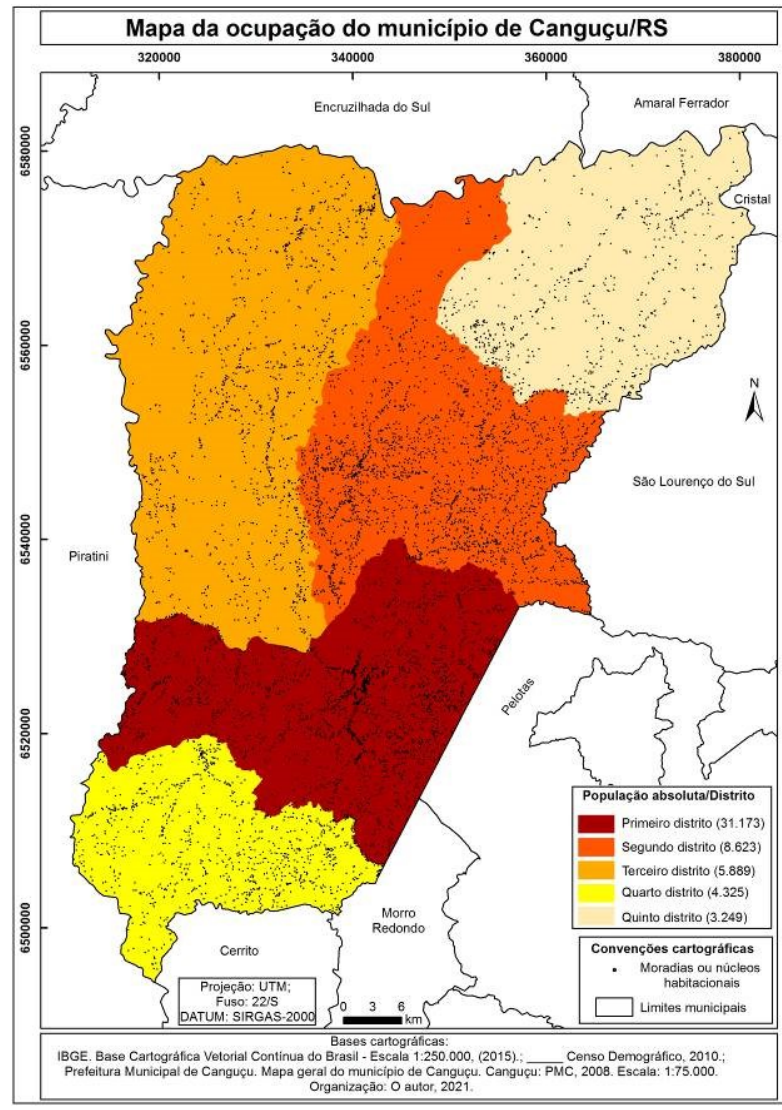

Figura 6 - Mapa demográfico.

Fonte: PMC (2008); Organização: Os autores, 2021

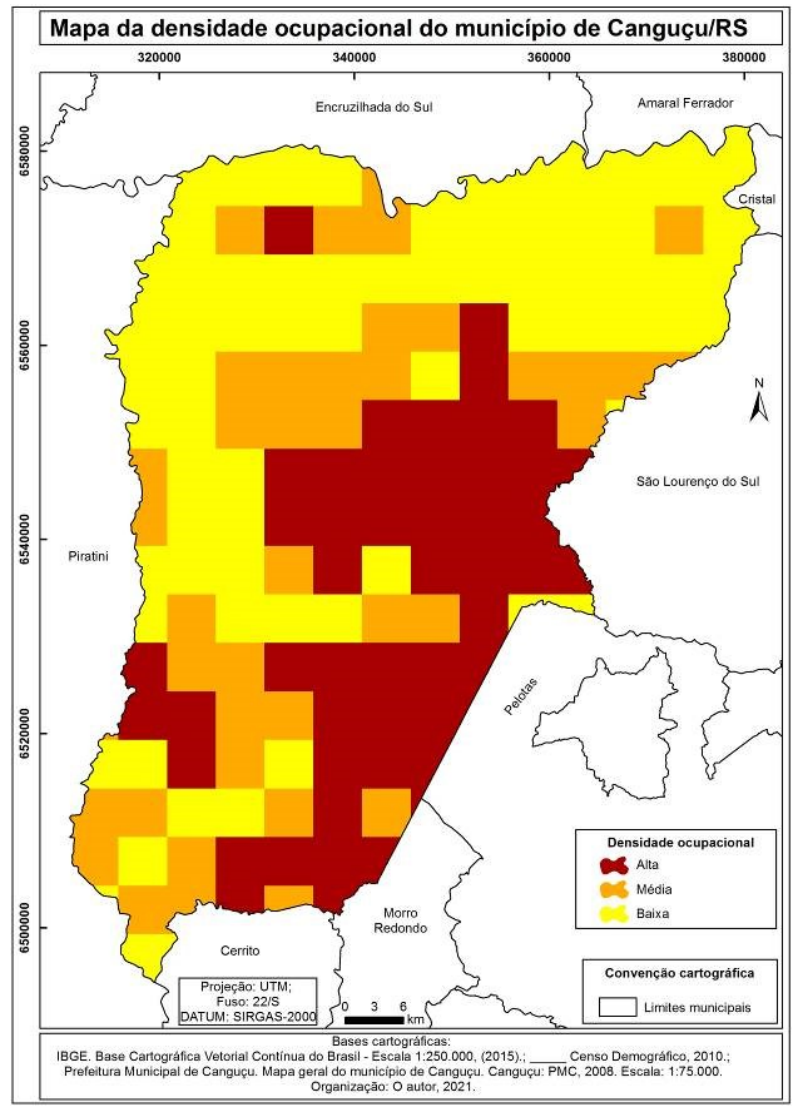

Figura 7 - Densidade ocupacional.

Fonte: PMC (2008); Organização: Os autores, 2021

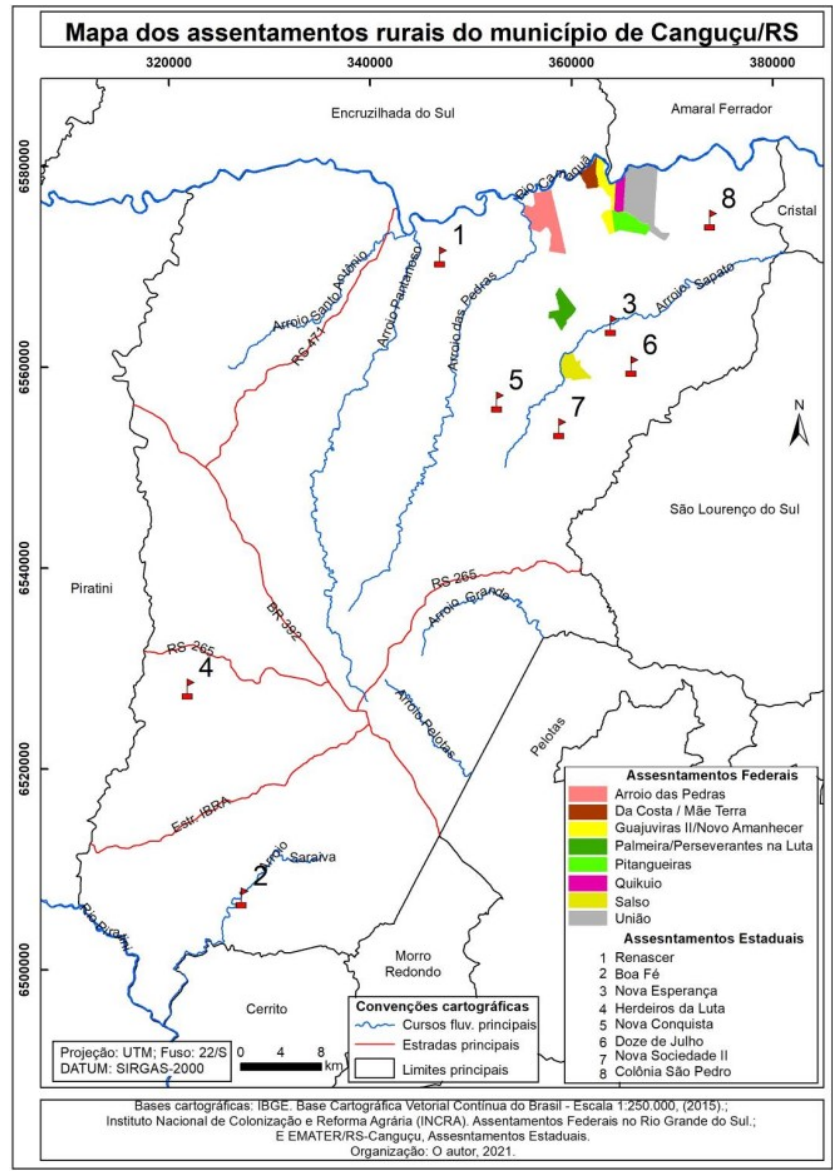

Figura 8 - Assentamentos rurais.

Organização: Os autores (2021). 


\subsection{Espacialização dos usos e coberturas atuais da terra}

O município de Canguçu apresenta um padrão bastante heterogêneo de usos e coberturas da terra, destacando-se o predomínio, em área, das classes de campo nativo com formação herbácea, seguido da classe de cobertura arbórea. As áreas de lavouras e solo exposto também são significativas no município. A Figura 11-A identifica uma área típica de campo nativo em Canguçu, localizada ao nordeste. Na Figura 9 temos a distribuição (\%) e na Figura 10 a espacialização dos usos e coberturas da terra da área de estudo.

\subsubsection{Campo nativo}

$\mathrm{Na}$ área de estudo, a cobertura da terra de campo nativo é a predominante, caracteristicamente constituindo o espaço ideal para a pecuária. Compreende $1.258,67 \mathrm{~km}^{2}$, ou mais de 35\%, de Canguçu. É mais representativa sobre áreas de relevo plano-colinoso e está localizada ao centro e nordeste da área de estudo. Também é representativa ao noroeste e ao sul sobre relevo com declividades mais acentuadas. Em todos os casos, é a cobertura que se sobressai e caracteriza, sobretudo, médias e grandes propriedades.

Os processos erosivos associados aos campos nativos são um tipo de uso que sofre menos com os processos erosivos. As áreas de campo nativo tornam-se muito suscetíveis aos processos erosivos quando as declividades são acentuadas e há uso intensivo pela pecuária.

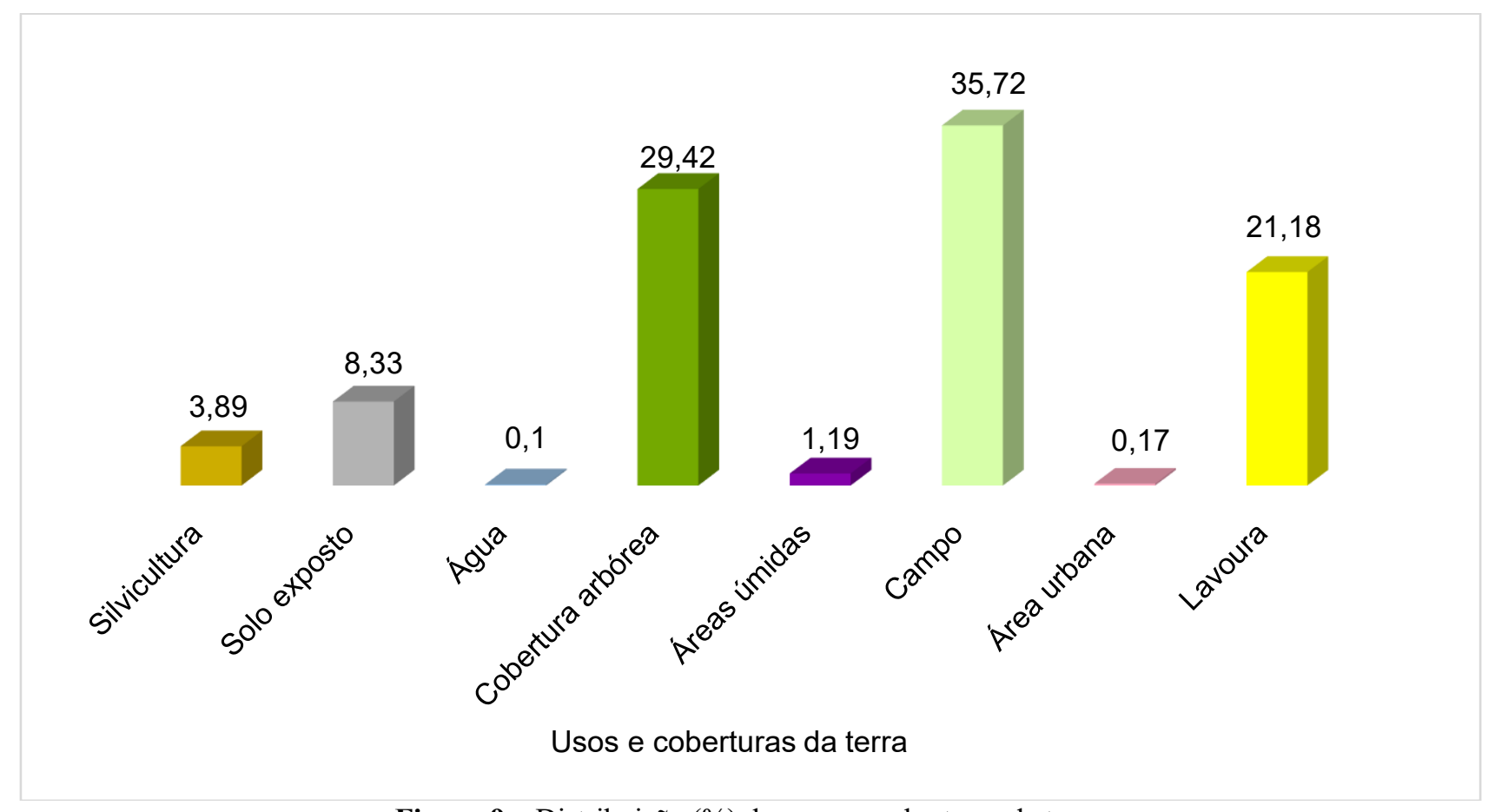

Figura 9 - Distribuição (\%) dos usos e coberturas da terra

Organização: Os autores (2021). 


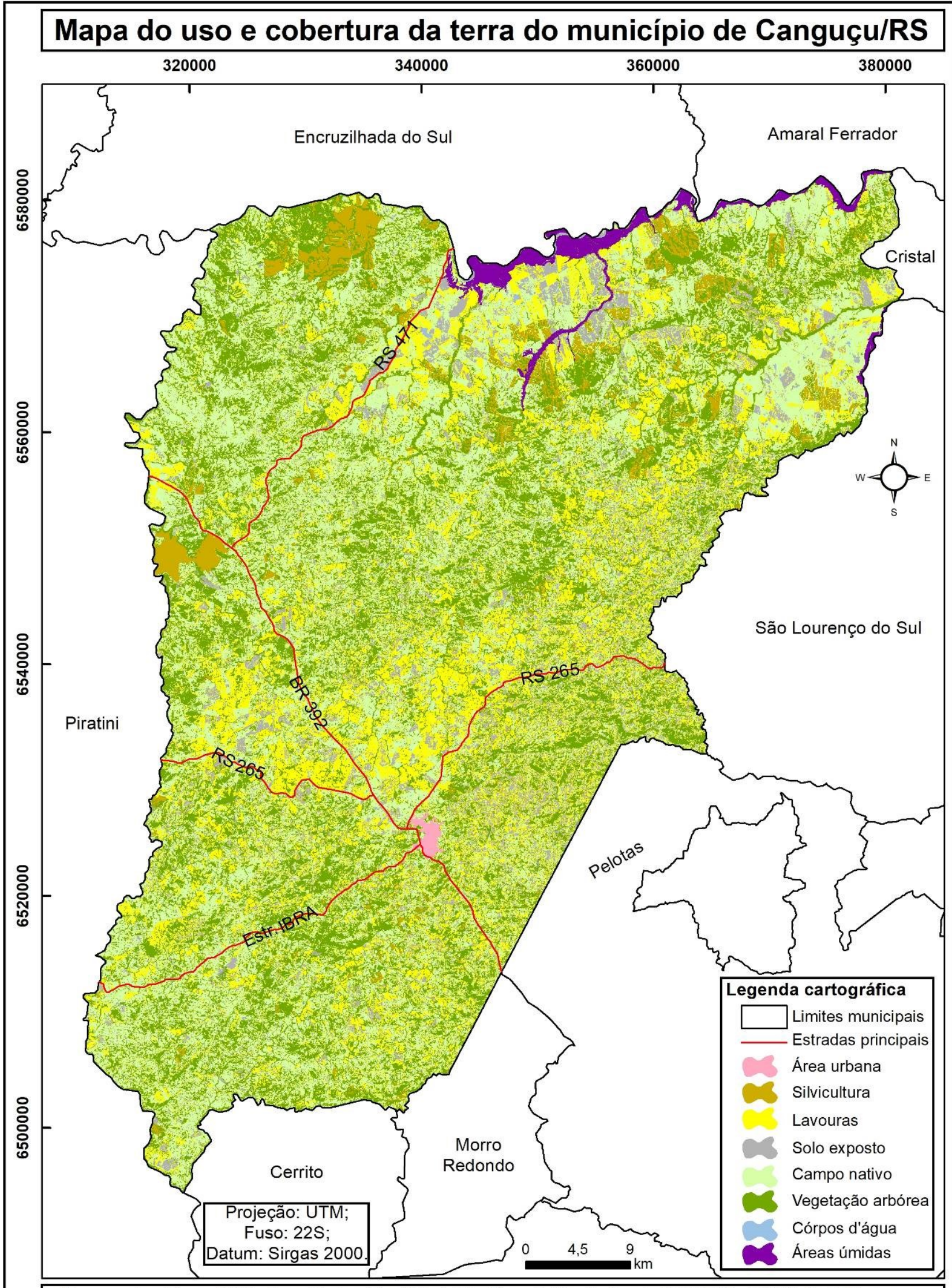

Bases cartográficas: IBGE - Base Cartográfica Vetorial Contínua do Brasil - Escala 1:250.000 - (2015); Earth Explorer Mapeamento do uso e cobertura do solo realizado a partir de classificação digital supervisionada e vetorizações, através de composição colorida natural com as bandas 4/3/2/8 da data de 24/03/2019 do Satélite Sentinel 2B; Elaboração: Autor, 2021.

Figura 10 - Usos e coberturas da terra Organização: Os autores (2021). 


\title{
3.2.2. Vegetação arbórea
}

A segunda maior área de uso e cobertura refere-se à mata nativa, ocupando $1.036,99 \mathrm{~km}^{2}$, ou quase $30 \%$ da área de estudo. A expressividade desse uso e cobertura é compreensível, pois no município de Canguçu há uma grande densidade de cursos fluviais e ao longo deles ainda prevalece a mata ciliar.

Além de ser comum ao longo dos cursos fluviais, a mata nativa também prevalece nas áreas de declividades acentuadas com solos pedregosos (trabalhos in loco), uma vez que são lugares de difícil acesso e inadequadas para o uso de máquinas agrícolas. É um tipo de cobertura da terra menos suscetível aos processos erosivos. Apesar das discussões realizadas acerca do real potencial de proteção do solo pela cobertura vegetal de porte arbóreo, Cunha e Guerra (2009, p. 359), assinalam que:

\begin{abstract}
A cobertura vegetal reduz as taxas de erosão do solo através de sua densidade, da possibilidade de reduzir a energia cinética das chuvas, através da intercepção de suas copas, e de formar húmus, importante para a estabilidade e teor de agregados dos solos. Tem papel importante na infiltração e na redução do escoamento superficial.
\end{abstract}

Essas observações destacadas anteriormente também são corroboradas por Coelho Netto (2009), que indica as múltiplas funções da cobertura vegetal, como a interceptação de parte da precipitação e o aumento da infiltração. A Figura 11-B representa o aspecto típico dessa cobertura da terra na área de estudo, perfazendo um fundo de vale e elevado topográfico.

\subsubsection{Lavouras}

Ocupando a terceira maior proporção da área de estudo, tem-se o uso da lavoura, com $746,49 \mathrm{~km}^{2}$, ou pouco menos de $22 \%$ dessa área. Canguçu é um importante polo da agricultura gaúcha, fortalecido especialmente pelo seu caráter familiar, mas também ocorrendo médias e grandes lavouras. As lavouras de maior porte se localizam na porção Norte do município, em especial no segundo e terceiro distrito.

Quanto à suscetibilidade aos processos erosivos desse tipo de uso e cobertura em questão, varia conforme as técnicas usadas pelos agricultores. Geralmente, os grandes produtores empregam mais tecnologia em suas lavouras, o que diminui a erosão dos solos, aspecto também observado ultimamente por parte dos pequenos agricultores. Ainda assim, as áreas que mais sofrem com os processos erosivos são as da agricultura familiar, tópico que também havia sido destacado por Cunha et al. (1997). A Figura 11-C apresenta uma área típica de lavoura em processo de crescimento. 
Viera (2012) observou que, mesmo em áreas de lavouras onde o solo se encontra coberto pelas plantas, pode haver perdas maiores para erosão se comparada à cobertura vegetal nativa. Segundo esse autor:

É sabido, no entanto, que determinadas espécies de plantas cultivadas nunca alcançam a mesma densidade que a vegetação natural, submetida às duras leis da concorrência biológica. Folhas e ramos constituem, aqui, uma tela de proteção menos eficaz contra o bombardeio do solo pelas gotas das chuvas (erosão pluvial). [...] A agricultura implica, portanto, em si mesma um risco de degradação dos solos, que aumenta a suscetibilidade aos fenômenos morfogenéticos, como, por exemplo, às enxurradas (escoamento superficial) (VIERA, 2012, p. 48)

\subsubsection{Solo exposto}

As áreas de solo exposto caracterizam lugares utilizados para extração de cascalho, as próprias estradas e principalmente lavouras em preparo para o plantio ou em processo de germinação, as quais permanecem temporariamente descobertas. Portanto, essa classe de uso permanece, em geral, porém temporariamente, nessa condição. Entre todos os usos e coberturas destacados na presente pesquisa, essas são as áreas que mais sofrem com os processos erosivos na área de estudo, principalmente em episódios pluviométricos extremos. Nas palavras de Guerra (2009, p. 171): “A ausência da cobertura vegetal facilita o impacto das gotas de chuva, fazendo com que os agregados se quebrem, crostas sejam formadas na superfície do solo, o que aumenta os feitos do escoamento superficial, causando maiores taxas de erosão".

Os processos erosivos mais facilmente se instalam sobre áreas de solo exposto e são ainda intensificados por fatores como, contato solo-rocha abrupto, descontinuidades litológicas e pedológicas, além de encostas íngremes (CUNHA; GUERRA, 2010). Solos expostos cobrem uma área de 293,74 km², ou pouco mais de $8 \%$ da área de estudo. A Figura 11-D representa uma área de lavoura com solo exposto.

\subsubsection{Silvicultura}

Com área de 137,21 km², ou mais de 3\% de Canguçu, destacam-se as áreas de silvicultura. Elas são mais expressivas nas grandes propriedades e mais concentradas ao norte da área de estudo. Nas pequenas propriedades rurais também é praticada a silvicultura, a qual a lenha, como produto florestal, é muito utilizada na cura do fumo.

Apesar de muitas controvérsias sobre esse tipo de cultura, a destacar o baixo índice da fauna nesses ambientes, ela também apresenta muitos aspectos positivos. Em Canguçu, Ehlert (2010, p. 5) observou que: 
[...] é possível estabelecer a produção rural com recuperação e conservação ambiental, além do cumprimento das legislações vigentes. Implantando-se projetos de silvicultura, viabilizou-se o uso de áreas improdutivas e de baixa capacidade produtiva em potenciais atividades com geração de renda aliada à preservação.

O autor anteriormente citado traz ainda uma observação importante sobre a silvicultura para as realidades regionais e locais, afirmando que essa atividade "vem contribuindo na construção do conhecimento e de uma nova visão do agronegócio para o município e região" (EHLERT, 2010, p. 23). A Figura 11-E apresenta uma área típica de silvicultura em grande propriedade.

\subsection{6 Áreas úmidas}

Primeiramente, na análise do conceito das áreas úmidas, é importante destacar as considerações de Junk e Piedade (2015, p. 23-24), os quais as consideram como tendo "papel importantíssimo no ciclo hidrológico, e que elas são recursos hídricos de suma importância econômica, social e ecológica".

Grosso modo, áreas úmidas funcionam como uma "esponja", ou seja, nos períodos de chuvas, elas absorvem água e nos períodos de estiagens, liberam água, aspecto que também contribui para a vazão dos cursos fluviais. Elas são muito comuns junto às cabeceiras de drenagem, formadoras dos primeiros cursos fluviais. Formam as áreas regionalmente conhecidas como "banhados".

Essas áreas úmidas também são comuns nas áreas ciliares dos cursos fluviais de ordem expressiva, lugares onde ocorrem extravasamento periódico das águas em consequência das cheias. Conceituação mais apropriada para esses ambientes é discutida por Simioni e Guasselli (2017, p. 43), os quais empregam o termo "Banhado" quando se referem às áreas úmidas. Segundo esses autores,

O termo Banhado refere-se a um tipo de Área Úmida que apresenta alta complexidade e grande diversidade de gradientes ambientais. Estes ecossistemas são caracterizados pela presença de: i) depósitos paludiais e turfas; ii) solos hidromórficos; e iii) presença de macrófitas aquáticas. São regulados pelos pulsos de inundação, permanecendo constante ou temporariamente inundados, com a presença de vegetação adaptada às flutuações do nível da água e uma biota característica.

As áreas úmidas ocupam $42,15 \mathrm{~km}^{2}$, ou pouco mais de $1 \%$ da área de estudo. Elas ocorrem junto às margens do rio Camaquã e são áreas bastante utilizadas para o cultivo de arroz irrigado, inclusive. A Figura 11-F representa uma área úmida. 


\subsection{7. Área urbana}

A área urbana abrange $5,92 \mathrm{~km}^{2}$, ou $0,17 \%$ de Canguçu, e se localiza ao sudeste do município. Segundo dados do IBGE (2010), a população urbana é de 19.694 habitantes, menos de $40 \%$ da população total.

O meio urbano de Canguçu é provido sobretudo pelo setor terciário da economia, com mínima participação do setor secundário. O setor de serviços é razoavelmente completo, com muitos consultórios médicos e odontológicos, escritórios, agências bancárias etc. O comércio também é bastante completo, com muitas redes de lojas e supermercados, fortemente dinamizados pelo poder de compra dos agricultores familiares. Nesse sentido, Bandeira (2017, p. 139) observa que: "[...] é na cidade (lugar central) que a maioria dos moradores do campo, principalmente os pequenos agricultores, adquirem bens e serviços, tanto para atender as necessidades das atividades agrárias como para as suas necessidades pessoais".

Do ponto de vista socioambiental, assim como aspecto comum em praticamente todos os centros urbanos do Brasil, há muitos conflitos de ocupação. A cidade de Canguçu, situada sobre relevo ondulado, é área de nascentes fluviais, sendo comum a ocupação sobre essas áreas de preservação permanente. Uma visão parcial da cidade é mostrada na Figura 11-G.

\subsubsection{Corpos d'água}

Os corpos d'água ocupam uma área de $3,48 \mathrm{~km}^{2}$, ou $0,1 \%$. Não existem, no município de Canguçu, grandes represas. Em grande parte, o que se tem são pequenos represamentos de água para servir de bebedouro aos animais e, também, alguns poucos parques aquáticos, como mostra a Figura 11-H. 


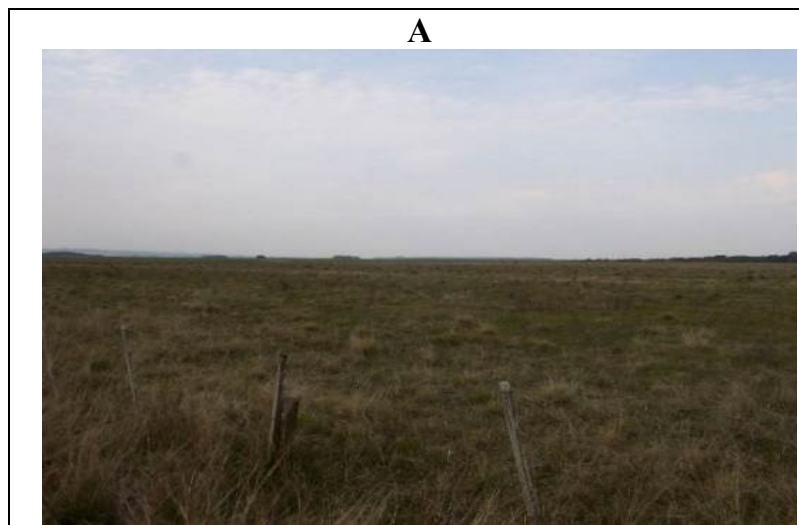

Campo nativo composto por gramíneas (Coordenadas: $31^{\circ} 01^{\prime} 54^{\prime}$ " e 52 19 '04" Visão: NE); Fonte: Os autores (2019).

\section{C}

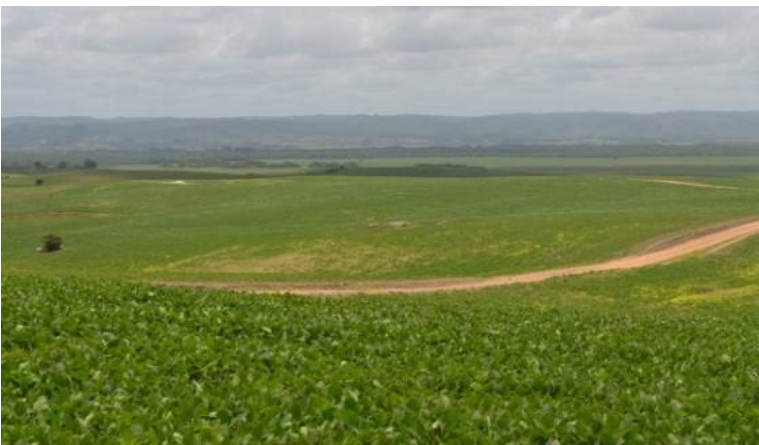

Lavoura de soja (Coordenadas: 30'59'46" e 52³3'54" Visão: W); Fonte: Trentin (2019).

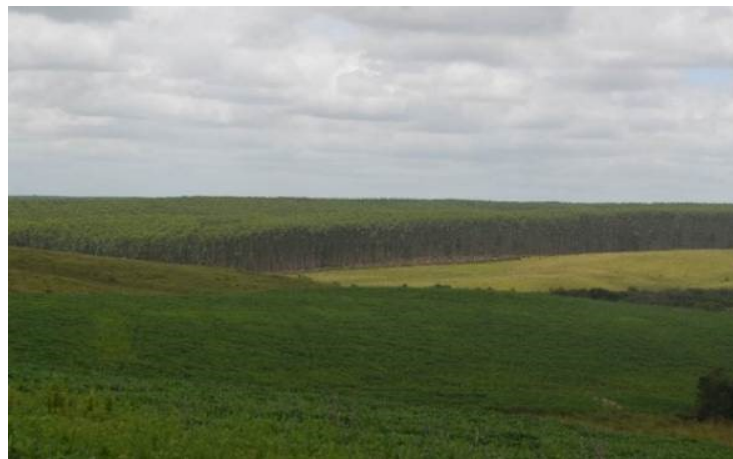

Silvicultura (Coordenadas: 31 ${ }^{\circ} 02^{\prime} 01^{\prime \prime}$ e 52 $36^{\circ} 06^{\prime \prime}$ Visão: W); Fonte: Trentin (2019).

\section{G}

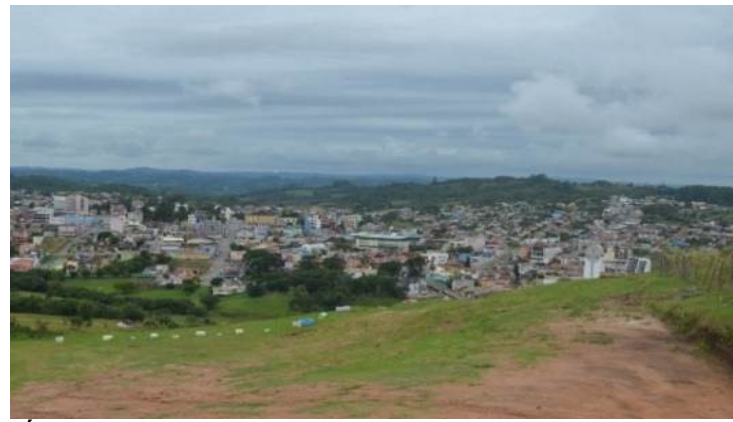

Área urbana (Coordenadas: $31^{\circ} 23^{\prime} 50^{\prime \prime}$ e 52 $41^{\prime} 19^{\prime \prime}$ Visão: SE); Fonte: Trentin (2019).

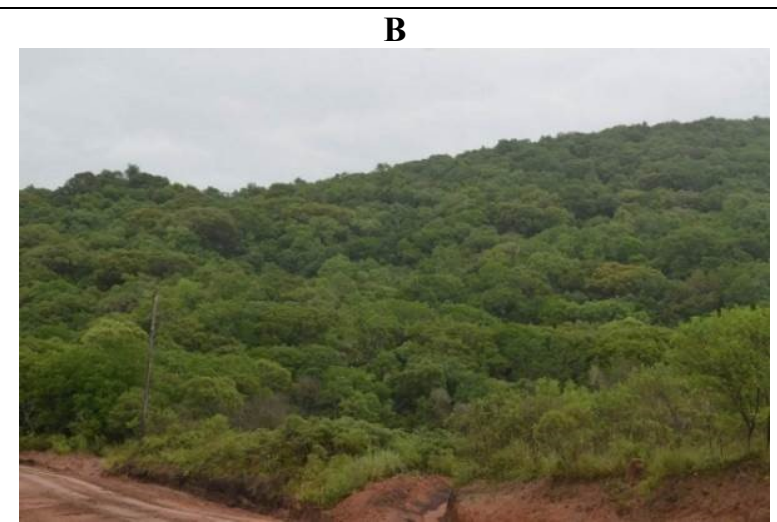

Cobertura arbórea nativa (Coordenadas: $31^{\circ} 27^{\prime} 52^{\prime \prime} \mathrm{e}$ 52 48'13" Visão: W); Fonte: Trentin (2019).

\section{D}

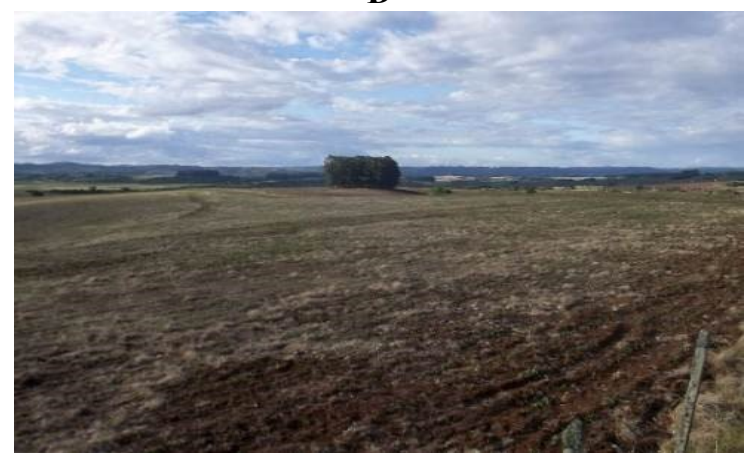

Solo revolvido preparado para cultivo (Coordenadas: 31 ${ }^{\circ} 03$ '33"S e 52 40'39" Visão: NO); Fonte: Os autores (2019).

$\mathbf{F}$

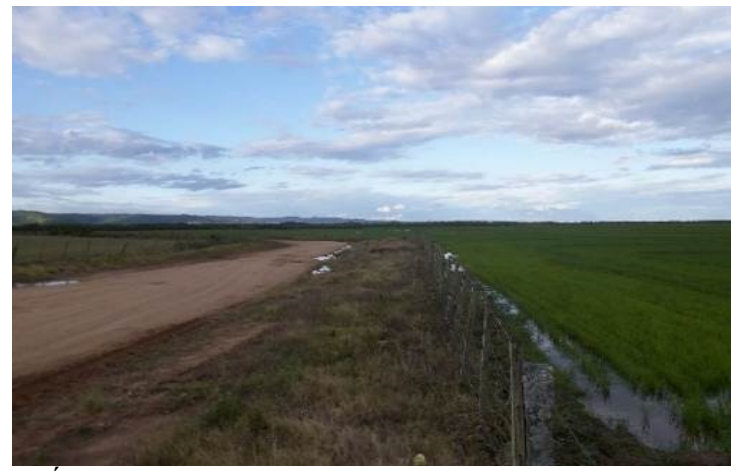

Área úmida próxima ao rio Camaquã (Coordenadas: 3059’34” e 52³9’00” Visão: L); Fonte: Os autores 2019).

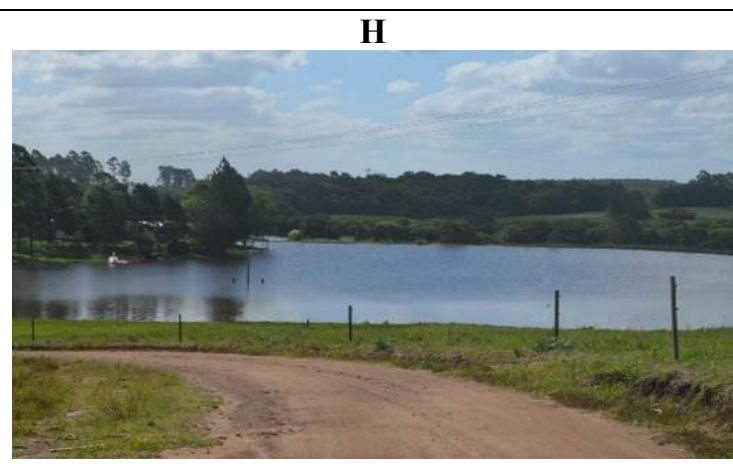

Corpo d'água em um parque aquático (Coordenadas $31^{\circ} 15^{\prime} 57^{\prime \prime}$ e $52^{\circ} 35^{\prime} 41^{\prime \prime}$ Visão: W); Fonte: Trentin (2019).

Figura 11: Representação dos usos e coberturas da terra 


\section{CONSIDERAÇÕES FINAIS}

Conhecer as características dos usos, ocupações e coberturas da terra mostra-se importante para as políticas de gerenciamento ambiental. $\mathrm{Na}$ área de estudo foi observado que existem potencialidades e suscetibilidades ambientais, as potencialidades estão representadas tanto pelas características socioeconômicas pertencentes a agricultura familiar quanto pelas coberturas nativas representativas em área.

As áreas de solo exposto, principalmente, representam as maiores suscetibilidades no município, mesmo que tratando-se de áreas transitórias nessa condição, pois representam em grande parte, solo revolvido para cultivos e ou em processo de germinação ou pós colheita.

Considerou-se a metodologia utilizada satisfatória para os objetivos propostos, podendo-se confirmar através dos dados de usos, coberturas e ocupação da terra, as características observadas para os distritos desse município.

Os trabalhos de campo foram importantes tanto no sentido de reconhecimento da área de estudo quanto para adequações dos produtos obtidos em gabinete. Também é valido destacar que nesse tipo de pesquisa denotou-se a importância de o sujeito pesquisador ter familiaridade com o objeto de estudo.

O trabalho pode auxiliar a propostas de gestão e planejamento municipal, destacando potencialidades que possam ser aproveitadas e dinamizadas e suscetibilidades que devem ser mitigadas.

\section{REFERÊNCIAS}

ARENDT, H. A. A condição humana. Rio de Janeiro: Forense universitária, 1987.

BANDEIRA, S. M. A relação campo-cidade em Canguçu/RS: Repercussões do aumento do poder de consumo da juventude rural. Universidade Federal do Rio Grande do Sul, Instituto de Geociências, Programa de Pós-Graduação em Geografia, Porto Alegre, RS-BR, 2017. (Tese de Doutorado)

CHAVES, M., PICOLI, M., \& SANCHES, I. (2020). Recent applications of Landsat 8/OLI and Sentinel-2/MSI for land use and land cover mapping: A systematic review. Remote Sensing, 12(18), 3062. https://www.mdpi.com/2072-4292/12/18/3062.

CUNHA, S. B.; GUERRA, A. J. T. Degradação ambiental. In: GUERRA, A. J. T.; CUNHA, S. B (Org.). Geomorfologia e meio ambiente. $9^{\circ}$ ed. Rio de Janeiro: Bertrand Brasil, 2010.

COTRIM, M. S. 'Pecuária familiar' na região da Serra do Sudeste' do Rio Grande do Sul: um estudo sobre a origem e a situação socioeconômica do pecuarista familiar no município de Canguçu/RS. Universidade Federal do Rio Grande do Sul - Programa de Pós-Graduação em Desenvolvimento Rural. Porto Alegre, 2003. (Dissertação de Mestrado). 
BERNARDES, J. A.; FERREIRA, F. P. M. Sociedade e natureza. In: CUNHA, S. B.; GUERRA, A. J. T. A questão ambiental: diferentes abordagens. $8^{\mathrm{a}}$ ed. Rio de Janeiro: Bertrand Brasil, 2012.

COELHO NETTO, A. L. Hidrologia de encosta na interface com a geomorfologia. In: GUERRA, A. J. T. e CUNHA, S. B. (org.). Geomorfologia: uma atualização de bases e conceitos. Rio de Janeiro: Bertrand Brasil, 2009. p. 93 - 147.

CUNHA, N. G.; SILVEIRA, R. J. C.; SEVERO, C. R. S.; NUNES, M. L.; SOARES, M. J. e COSTA, C. N. Estudo dos solos do município de Canguçu. Pelotas: EMBRAPA-CPACT; Ed. UFPEL, 1997.

EHLERT, E. A silvicultura contribuindo para o desenvolvimento rural sustentável em propriedades rurais de Canguçu, RS. UNISINOS, São Leopoldo, 2010. (Monografia de especialização).

GRIGOLETTI, N. E. Evolução histórica da agricultura do município de Canguçu. In: BENTO, C. M. (Org.). Revista dos 200 anos de Canguçu. Comemorativa dos 200 anos de Canguçu, aos 500 anos do Descobrimento do Brasil e ao ingresso no Terceiro Milênio. Canguçu: Acandhis, 2000. p. 53 - 55.

GUERRA, A. J. T. Processos erosivos nas encostas. In: GUERRA, A. J. T. e CUNHA, S. B. (org.). Geomorfologia: uma atualização de bases e conceitos. Rio de Janeiro: Bertrand Brasil, 2009. p. 149 - 207.

INSTITUTO BRASILEIRO DE GEOGRAFIA E ESTATÍSTICA (IBGE). Manual Técnico de Uso da Terra. In: Manuais Técnicos em Geociências - $\mathrm{N}^{\mathrm{0}} 7$. Instituto Brasileiro de Geografia e Estatística. Rio de Janeiro/RJ, 2013.

INSTITUTO BRASILEIRO DE GEOGRAFIA E ESTATÍSTICA (IBGE). Projeto RADAMBRASIL. Levantamento de recursos naturais (Folha SH. 22 Porto Alegre e parte das Folhas SH.21 Uruguaiana e SI.22 Lagoa Mirim). Instituto Brasileiro de Geografia e Estatística, Rio de Janeiro, CD-ROM. 1986.

INSTITUTO BRASILEIRO DE GEOGRAFIA E ESTATÍSTICA (IBGE). Manual Técnico de Uso da Terra. In: Manuais Técnicos em Geociências - $\mathrm{N}^{\circ} 7$. Instituto Brasileiro de Geografia e Estatística. $3^{\circ}$ edição. Rio de Janeiro/RJ, 2013.

INSTITUTO BRASILEIRO DE GEOGRAFIA E ESTATÍSTICA (IBGE). Base Cartográfica Contínua do Brasil na escala de 1:250.000. 2015. Disponível em: ftp://geoftp.ibge. gov.br/mapeamento-sistematico/base-vetorial-continua-escala-250mil/ Acesso em: $10 \mathrm{dez} 2017$.

INSTITUTO BRASILEIRO DE GEOGRAFIA E ESTATÍSTICA (IBGE). Base de Solos do ano de 2013. Disponível em: http://mapas.ibge.gov.br/bases-e-referenciais/cartas-tematicas.html. Acesso em: 06 nov. 2018.

INSTITUTO BRASILEIRO DE GEOGRAFIA E ESTATÍSTICA - IBGE. Banco de Dados Cidades@. Disponível em: http://www.cidades.ibge.gov.br/xtras/perfil.php?lang=\&codmun= 430450\&search=rio-grande-do-sul|cangucu. Acesso em: 4 de Janeiro de 2019.

INSTITUTO BRASILEIRO DE GEOGRAFIA E ESTATÍSTICA (IBGE). Censo Demográfico do Rio Grande do Sul, 2010. Disponível em: http://www.cidades.ibge.gov.br/xtras/perfil.php?lang=\& codmun=430450\&search=rio-grande-do-sul|cangucu. Acesso em: 4 de Janeiro de 2019. 
INSTITUTO NACIONAL DE COLONIZAÇÃO E REFORMA AGRÁRIA (INCRA) Assentamentos. Disponível em: http://www.certificacao.incra.gov.br/csv-shp/export-shp.py. Acesso em: 27/06/2020.

BENTO, Cláudio Moreira. Canguçu reencontro com a história: um exemplo de reconstituição de memória comunitária. 2. ed. Barra Mansa - RJ: ACANDHIS/Gráfica e Editora Irmãos Drumond Ltda, 2007.

DE DAVID, C. Estratégias de reprodução familiar em assentamentos: limites e possibilidades para o desenvolvimento rural em Canguçu - RS. Programa de Pós-Graduação em Geografia da Universidade Federal de Santa Catarina (UFSC). Florianópolis, 2005. (Tese de doutorado)

DUTRA, E. J. S. A PRODUÇÃO DE FUMO EM PERSPECTIVA: A tipologia dos produtores de fumo no município de Canguçu, Rio Grande do Sul, Brasil. Universidade Federal do Rio Grande do Sul, Instituto de Geociências, Programa de Pós-Graduação em Geografia, Porto Alegre, BR-RS, 2015. (Tese de Doutorado)

FLORENZANO, T. G. Sensoriamento Remoto para Geomorfologia. In: FLORENZANO, T. G. (org.). Geomorfologia: conceitos e tecnologias atuais. São Paulo: Oficina de Textos, 2008.

JUNK, W. J.; PIEDADE, M. T. F. Áreas Úmidas (AUs) Brasileiras: Avanços e Conquistas Recentes. Boletim ABLimno, v. 41, n. 2, p. 20-24, 2015.

HASENACK, H.; WEBER, E. (ORGS.) Base cartográfica vetorial contínua do Rio Grande do Sul - escala 1:50.000. Porto Alegre: UFRGS - IB - Centro de Ecologia. 2010. 1 DVD-ROM (Série Geoprocessamento, 3).

SIMIONI, J. P. D.; GUASSELLI, L. A. Banhados: abordagem conceitual. Boletim Geográfico do Rio Grande do Sul, Porto Alegre, n. 30, p. 33-47, set. 2017.

VALERIANO, D. M. Processamento digital de dados do MSS-Landsat aplicado ao mapeamento da cobertura da terra da planície costeira do rio Tubarão, S.C.: metodologia e estimativa de exatidão de classificação. Instituto Nacional de Pesquisas Espaciais, São José dos Campos, 1984. Dissertação (Mestrado em Sensoriamento Remoto)

VIERA, V. Município de Canguçu/RS: O relevo e sua morfodinâmica como condicionantes do dinamismo agrícola. Universidade Federal do Rio Grande do Sul, Instituto de Geociências, Programa de Pós-Graduação em Geografia, Porto Alegre, BR-RS, 2012. (Tese de Doutorado) 